
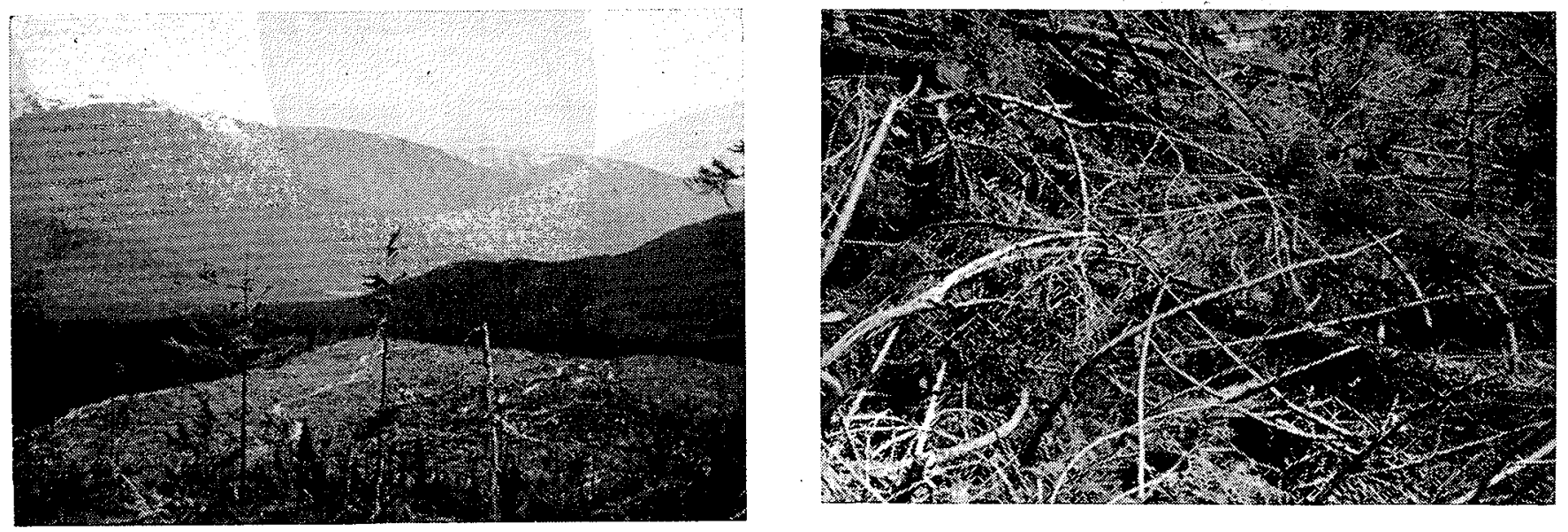

\title{
The Relevance of Current Hazard Stick Reading to the Moisture Content of Logging Slash
}

\author{
By GY. PÉCH
}

"The itse of hazard sticks as a guide for buming slash is discussed, attention being called to the irreleoncy of current hazard stick readings to both the moisture content of logging slash and the ease with which the fire spreads and causes spotting."

\begin{abstract}
Seven composite samples of western red cedar and western hemlock logging slash of 0.25 to 2 inches diameter were exposed on top of and within the bottom third of a fuel bed in the interior wet belt of British Columbia in August 1965. Their moisture contents were measured regularly 24 hours a day and compared with the moisture content of an exposed B.C. hazard stick on the basis of both the hourly drying rates on 1 clear. day and the daily loss of moisture, relative to the morning maximum moisture content, for a period of 6 drying days after rain. The absolute moisture content values, the hourly rates of drying, and the daily fluctuation of the moisture content of the hazard stick differed from those of the fuel samples at all times. It was concluded that cedarhemlock slash fuel moisture content cannot be predicted numerically from an individual measurement of the moisture content of freely exposed hazard sticlss in those years when the slash retains a tight bark. Counting the number of drying days after rain proved to be of little practical value.
\end{abstract}

\section{Résumé}

En août 1965, sept échantillons (diamètro, 0.25 à 2 pouces) composés de déchets d'abattage (rémanents) en Thuya géant (Thuja plicata Donn) et en Pruche de l'Ouest (Tsuga heterophylla (Raf.) Sarg.) furent exposés au-dessus et au tiers inférieur d'une couche de combustible à l'intérieur de la zone humide en Colombie Britannique. Leur teneur en humidité était mesurée régulièrement 24 heures par jour et vérifiée avec un bâton indicateur de l'humidité des combustibles, sur la base
Canoda Department of Forestry and Rural Development, Forest Fire Research Institute, Ottawa.

Oxf. $431.2(711)$.

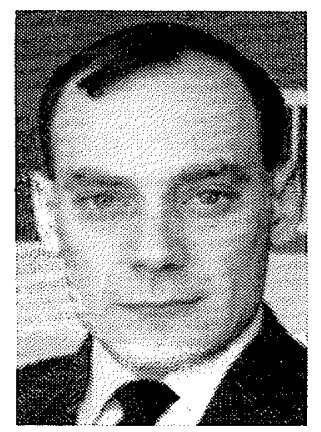

tant des taux horaires de dessication par journée ensoleillée que de la perte quotidienne d'humidité mesurée relativement à l'humidité matinale maximale pendant 6 jour's d'évaporation consécutive à une journée pluvieuse. Les valeurs de l'humidité absolue, les taux horaires de dessication et la fluctuation quotidienne de la teneur en humidité, obtenus par le bâton indicateur, différaient constamment des chiffres obtenus par mensurations directes.

L'auteur conclut que, lor'sque les rémanents conservent imperméable leur écorce, la teneur en humidité des combustibles constitués par les déchets de Thuya géant et de Pruche de l'Ouest ne pent être quantitativement déterminée avec un bâton indicateur. De plus, le calcul des jours d'évaporation après la pluie s'est avéré peu utile. Remise en question des bátons indicateurs ordinaires employés lor's des dits brûlages, vu l'inexactitude parfois des données qu'ils fournissent et la facilité avec laquelle le feu s'étend et se dissémine.

Throughout the interior wet belt of British Columbia and in some of the province's coastal areas, hazard or fuel moisture indicator sticks ${ }^{1}$ (Hardy, 1953) are employed extensively as indicators of the fine-fuel moisture content. In the Nelson Forest District, much of which lies in the wet belt region, the current hazard stick reading, in combination with the aggregate of four preceding daily readings, forms the basis of estimating fire danger.

${ }_{1}$ Hereafter referred to as hazard stick or stick. 
Hazard stick readings obtained in cut-over areas have been published in tabular form as guides for burning slash (Morris, 1966). On the Pacific coast more success has been associated with hazard sticks exposed under full canopy "particularly for the control of slash burns" (Anon., 1955).

Since fuel moisture content affects the flammability and combustion of forest fuels, its direct or indirect estimate can be of great practical value for controlling prescribed burns. It is a general belief among those promoting the use of exposed hazard sticks that "sunshine causes [the moisture content of] the fuel moisture indicator sticks, and the slash, to drop to about the same values at a particular site on any sunny summer afternoon" (Anon., 1955). They rely on the current hazard stick reading for timing the ignition of slash.

It is somewhat surprising, therefore, that the relevance of current hazard stick readings to the moisture content of logging slash appears to have but little direct support in the literature. Since Bryan's (1944) preliminary observations have become widely publicized, namely the apparent usefulness of comparing the readings of freely exposed hazards sticks with those of completely shaded ones as a guide for timing the ignition, several indirect studies have been reported on the relationship between these readings and the ease with which fires spread and spotted (Morris, 1953, 1958). The results were seemingly most heterogeneous and complex, suggesting in general that the burns were more successful when the stick readings were low than when they were high.

With the increasing interest in burning slash for hazard abatement in all the forest districts of British Columbia, it is of prime importance to analyze the moisture regimes of logging slash and to critically re-examine the relevance of the hazard stick moisture content, especially in the areas where hazard sticks are used as a guide for calculating fire danger and igniting logging slash.

\section{Location}

The study area, in 3-year-old logging slash, was located on a bench 5 miles northwest of the north end of Mabel Lake in the Enderby Forest Ranger District of British Columbia (Lat. 50 $54^{\prime} \mathrm{N}$., Long. $118^{\circ} 40^{\prime}$ W., Elev. 3,400 feet above M.S.L.). The site was typical of the undulating terrain found at moderate elevations throughout the British Columbia wet belt region.

Prior to logging, the site supported an overmature stand of decadent western red cedar (Thuja plicata Donn) and western hemlock (Tsuga heterophylla (Raf.) Sarg.) with a mixture of western white pine (Pinus monticola Dougl.) and some Douglas fir (Pseudotsuga menziesii (Mirb.) Franco) trees. As a result of the logging operation in late 1962, a fuel bed of mostly cedar and hemlock tree crowns, tops and broken or decaying cull material covered the ground irregularly up to a height of 2 to 4 feet. A detailed description of the forest stand and of the size and distribution of the logging slash has already been published (Muraro, 1967). An average fuel loading of 146 ton/acre was estimated for the entire cut-over area.

\section{Methods}

A fire weather station was established on a slightly elevated flat area of about 0.1 acre. The following instruments were put into operation: a Fuess hygrothermograph in a single-louvered, double-roofed plastic screen (Muraro, unpublished report) at 4.5 feet above ground level (the top of the fuel bed), a Casella siphoning rainfall recorder, a three-cup wind vane assembly 10 feet above the fuel bed, a Belfort bimetallic actinograph, and a Negretti-Zembra Jordan sunshine recorder. All instruments were checked daily and serviced either daily or weekly.

Various methods of measuring fuel-moisture changes were considered. Destructive sampling, the practice of regularly collecting a large number of samples from randomly selected locations and calculating the mean value of moisture content from wet and oven-dry weights, was judged unsatisfactory. Some of the major weaknesses of this method are that:

(a) it requires considerable labor when the sampling is repeated frequently,

(b) the results are not reproducible quantitatively, and

(c) it provides little if any continuity for the mean values of consecutive sampling periods owing to the large variance of each sample population.

The apparent advantage of random sampling, a statistical evaluation of the sampled population, is greatly offset by the lack of certainty that each sample population consistently includes the more important fuels in approximately the same proportions as the natural distribution.

In contrast, the method of exposing and intermittently weighing reproducible composite samples offers certain advantages. It provides continuous and accurate estimates of the amount of moisture and its rate and trend of change in certain fuels. The results can be repeated with freshly made samples. In addition, the method requires the least amount of expense for labor and equipment.

To derive the rates of moisture sorption in logging slash of various sizes, continuous fuel moisture estimates were needed. To obtain this information both qualitatively and quantitatively, intermittent weighing of reproducible composite samples was judged more suitable than destructive sampling.

Composite fuel samples were constructed from both cedar and hemlock branches separately. The branches were collected from logging debris with tight bark, well away from the experimental site. To prevent evaporative losses through the cut surfaces the ends of branches were sealed with warm wax. Several branches were held in one plane with two bicycle spokes led through the branches perpendicular to the long axis. Small gaps were left between adjacent branches to allow runoff of water.

All the branches comprising the fuel sample were weighed together. Thus the calculated moisture content values represented an average value for the particular diameter class. 
Altogether seven composite samples were constructed; five from hemlock branches and two from cedar branches, both cured by 3 years of weathering (Table 1). Six samples were suspended from aluminum angles at the top of the fuel bed, and the seventh was placed on wire racks within the bottom third of the fuel bed.

Table 1. Dimensions and places of exposure of cured cedar and hemlock logging slash fuel samples

\begin{tabular}{llccc}
\hline $\begin{array}{c}\text { Place } \\
\text { of } \\
\text { exposure }\end{array}$ & Species & $\begin{array}{c}\text { Branch } \\
\text { diameter } \\
\text { (in.) }\end{array}$ & $\begin{array}{c}\text { Branch } \\
\text { length } \\
\text { (in.) }\end{array}$ & $\begin{array}{c}\text { Number } \\
\text { of } \\
\text { branches }\end{array}$ \\
\hline $\begin{array}{l}\text { Top of } \\
\text { fuel }\end{array}$ & $\begin{array}{l}\text { (hemlock } \\
\text { (cedar }\end{array}$ & 2.00 & 14.9 & 4 \\
bed & 2.00 & 14.9 & 4 \\
$\begin{array}{l}\text { Bottom } \\
\text { Bhird of }\end{array}$ & hemlck & 1.00 & 20.0 & 6 \\
fuel bed & .50 & 21.8 & 11 \\
$\begin{array}{l}\text { Top of } \\
\text { fuel }\end{array}$ & $\begin{array}{l}\text { (hemlock } \\
\text { bed }\end{array}$ & .50 & 21.8 & 11 \\
\hline
\end{tabular}

For comparison with the composite fuel samples, a B.C. hazard stick was mounted on wire racks 10 inches above the ground at the fire weather station. The stick and fuel samples were weighed manually with an Ohaus triple-beam balance ${ }^{2}$ ance an hour for 24 hours a day, and at 30-minute intervals around sunrise and 1600 hours. Measurements were suspended whenever it rained.

With minor but frequent interruptions the experimental period lasted for 6 weeks. Early in September all fuel samples and the hazard sticks were oven-dried at $221^{\circ} \mathrm{F}$, and the field records of gross wet weights were converted to moisture contents as percentages of oven dry weight. No corrections were applied to compensate for the negligible amount of weathering losses, measured for the hazard stick and estimated for the fuel samples.

\section{Results and Discussion}

In the interior wet belt of British Columbia above 3,000 feet elevation, continuous drought periods in the summer months rarely exceed 10 to 12 days. ${ }^{3}$. Commonly a shower of at least 0.1 inch occurs on every third or fourth day. In 1965, between August 4 and September 10, there were 21 days with rain of at least 0.1 inch at the fire weather station. On 10 of these days more than 0.4 inch of rain fell, 4 days having more than 1.2 inches.

For qualitative comparisons of the fuel samples and the hazard stick moisture contents the two longest rainless periods between August 5 and 9 , and 14 and 19 have been selected. The fuel samples have been grouped as fast- and slow-reacting fuels, and the moisture contents of each fuel sample and of the hazard stick were plotted on a linear time scale (Figs. 1 and 2).

\footnotetext{
2 Capacity $2610 \mathrm{~g}$, resolution $0.05 \mathrm{~g}$ below $500 \mathrm{~g}, 0.1 \mathrm{~g}$ below $1,000 \mathrm{~g}$, and $0.5 \mathrm{~g}$ at full capacity.

${ }^{3}$ Personal communication, Mr. A. W. Jackson, Forest Meteorologist, Vancouver, B.C., 1966.
}

The 2-inch diameter hemlock and cedar, and the 1 -inch-diameter hemlock fuel samples have been designated as slow fuels on the basis of the differences between their daily maximum and minimum moisture contents, i.e. the daily fluctuation of their moisture content being consistently less than a third of that of the hazard stick.

In contrast, the fast-reacting 0.5 -inch-diameter hemlock and cedar, and the 0.25-inch-diameter hemlock fuel samples on top of the fuel bed had daily amplitudes consistently greater than half the daily amplitudes of the hazard stick.

The 0.5-inch diameter hemlock fuel sample exposed within the bottom third of the fuel bed was a fast fuel on the first and sometimes on the second day after rain but qualified among the slow fuels on subsequent days.

At all times except immediately after the cessation of the rain the dissimilarity between the moisture contents of the hazard stick and of the fuel samples is plainly evident.

Most striking perhaps is the variation in the response rates of the hazard stick and the fuel samples to both the diurnal and the irregular changes of weather. For a quantitative comparison of the drying rates, the drying period between sunrise and 1600 hours on August 9 was analyzed. Relevant information on air temperatures and relative humidities at screen height, and on the radiation flux densities (in langleys per hour) are shown in Table 2.

Table 2. Hourly air temperature ( $\mathrm{T})$, relative humidity ( $\mathrm{RH}$ ), and short wave radiant energy (SR), on August 9, 1965, at the fire weather station

\begin{tabular}{cccc}
\hline Time (hrs.) & T $\left({ }^{\circ} \mathrm{F}.\right)$ & RH (\%) SR (ly. hr. $\left.{ }^{-1}\right)$ \\
\hline 0100 & 56 & 90 & \\
0200 & 56 & 90 & \\
0300 & 55 & 89 & \\
0400 & 54 & 93 & \\
0500 & 54 & 94 & 1 \\
0600 & 57 & 88 & 13 \\
0700 & 61 & 86 & 17 \\
0800 & 62 & 80 & 30 \\
0900 & 66 & 76 & 50 \\
1000 & 72 & 60 & 60 \\
1100 & 76 & 50 & 67 \\
1200 & 78 & 45 & 65 \\
1300 & 79 & 38 & 60 \\
1400 & 81 & 37 & 49 \\
1500 & 83 & 35 & 2 \\
1600 & 74 & 39 & 16 \\
1700 & 59 & 80 & \\
\hline
\end{tabular}

A rain of 0.3 inch fell on August 8 between 1600 and 2030 hours. By midnight all water had evaporated from the hazard stick and fuel sample surfaces and they were gaining moisture by adsorbing water vapour from the atmosphere. Though their average moisture contents varied between 28.6 and $46.0 \%$ at sunrise, the moisture contents within their outermost wood and bark layers were nearly identical 
at or somewhat below the fiber saturation point.

The hourly rates of moisture loss, based on the average moisture content of each fuel sample and hazard stick at 0530 hours, have been plotted (Fig. 3 ) on the assumption that there is a proportionality between the drying rate and the square root of the drying period; that is, that the rate of moisture loss is a function of the rate of diffusion.

Three different curve patterns can be recognized:

(a) a symmetrical curve with a rapidly increasing and decreasing phase with a short transition in between from 0900 to 1000 hours (curve 1),

(b) an asymmetrical curve with a slowly rising phase reaching a plateau between 1130 and 1200 hours, followed by a short and very slowly declining phase (curves 2 and 4), and

(c) a quasi-sigmoid curve with the gradually increasing drying rate coming to a plateau between 0900 and 1000 hours, followed by a phase of nearly constant rate of drying lasting about 3 hours, and a subsequent phase with a very slowly declining drying rate (curves 3,5 , 6,7 and 8).

The thickness and texture of the outermost bark or woodlayers, or both, appear to be related to the various curve shapes. The 0.5 -inch-diameter dowels of the Douglas-fir hazard stick were not wax-coated on the end nor did they possess any bark. The diffusion of water vapor proceeded both longitudinally and radially through some thickness of Douglas-fir sapwood that had once been oven-dried by the manufacturer at the time of calibration. The lack of any bark and the oven drying (King and Linton, 1963) were probably most influential in determining the fast drying rate of the hazard stick and the shape of its drying-rate curve.

The bark on the 0.25 -inch-diameter hemlock and 0.5 -inch diameter cedar branches was smooth, skinlike, and less than 0.06 inch thick (curve shape b), the 2-and 1-inch-diameter hemlock branches had bark with fairly thick flat scales with deep furrows in between, while on the 2 inch-diameter cedar branches the bark showed a pattern of narrow but over 0.1 inch thick intersecting ridges of fibrous texture. The bark on the 0.5-inch-diameter hemlock branches was in between those on the 0.25- and 1 to 2-inch-diameter fuel samples and, though skinlike, was about 0.1 inch thick with small scales.

Taking into account that the maximum hourly drying rates of the fuel samples were $1 / 6$ to $2 / 3$ of

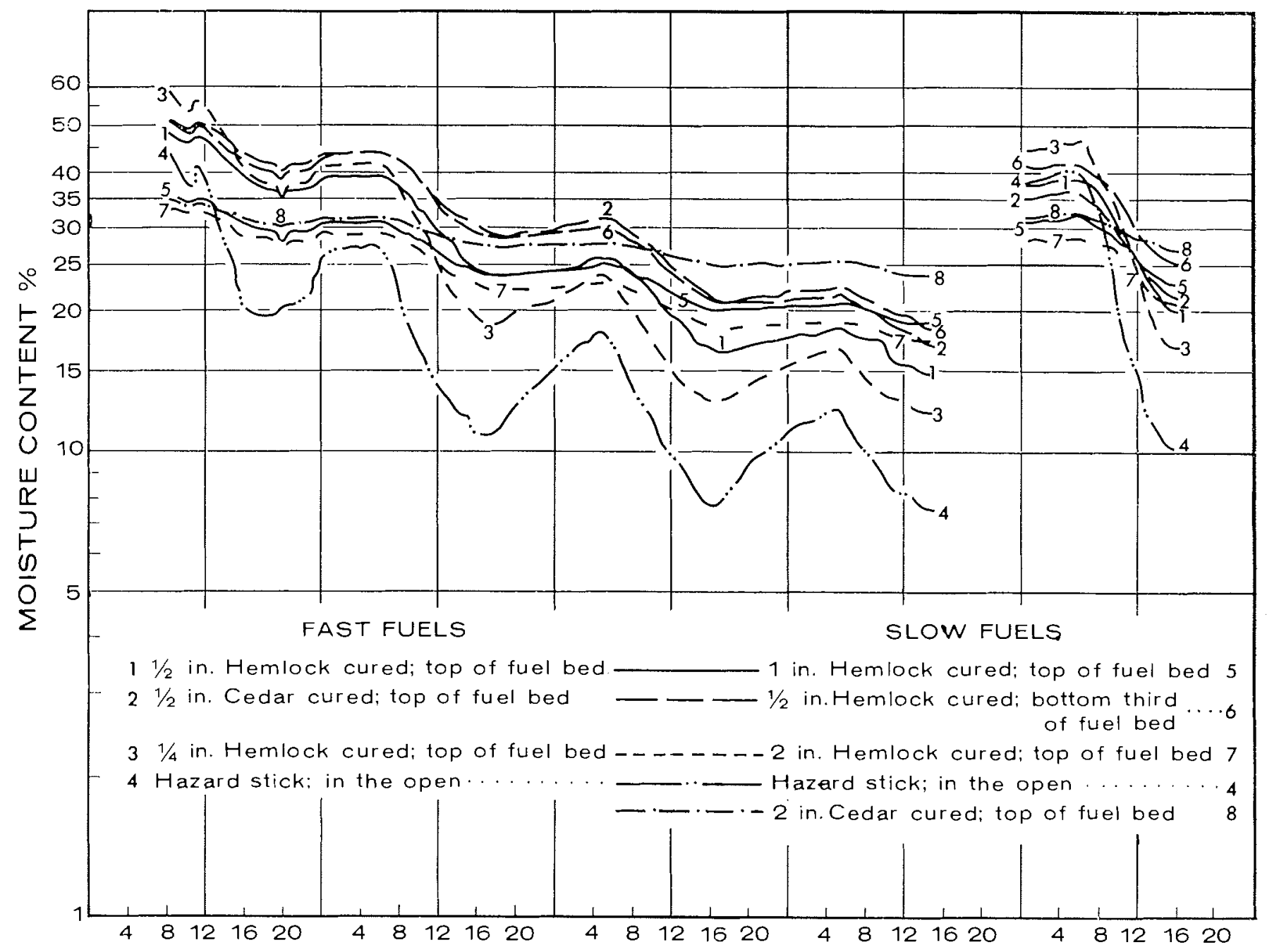

AUGUST 5th AUGUST 6th AUGUST 7th AUGUST 8th AUGUST 9th

Fig. 1. Continuous records of cedar-hemlock logging slash and freely exposed hazard stick moisture contents during 5 days following .61 inches of rain. Every fourth hour is indicated on the abscissa. 


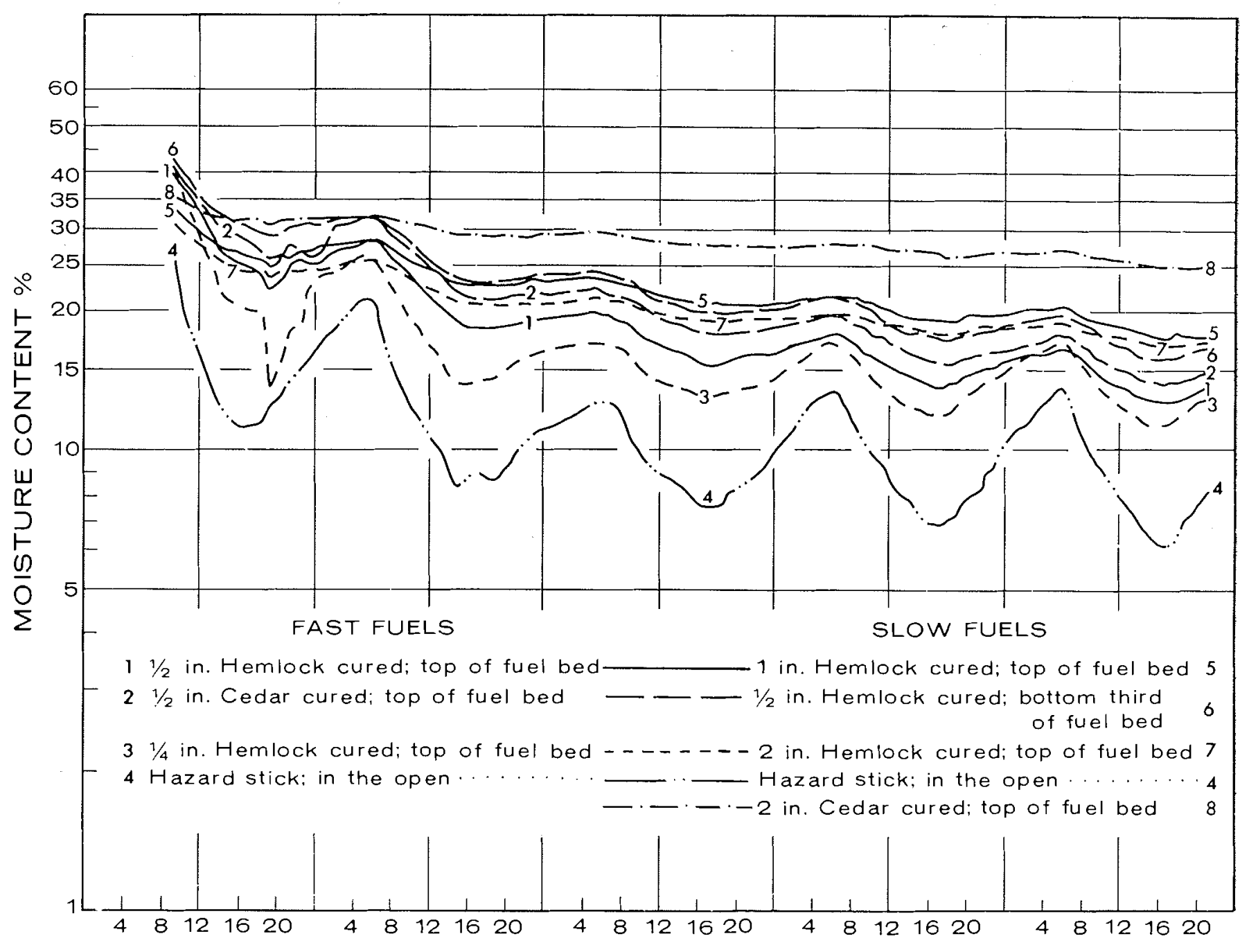

AUGUST 14th AUGUST 15th AUGUST 16th AUGUST 17th AUGUST 18th

Fig. 2. Moisture regimes of cedar-hemlock logging slosh and a freely exposed hazard stick during 5 days of drought follow-

that for the hazard stick, it is not surprising that neither their actual moisture contents nor the daily amplitude of their moisture-content fluctuations were ever identical.

The moisture regimes of cedar-hemlock fuel samples support Linton's (1962) conclusion that sudden weather changes cause a nearly exponential change in the surface concentration of fuel moisture, while the diurnal gain and loss of moisture is quasisinusoidal. The average moisture content curves (Figs. 1 and 2) reveal that following irregular changes of weather the exponential change is superimposed over the daily fluctuations of the moisture content, and the resulting curve shows a decrease in both the daily mean value and the daily fluctuation.

The duration of the exponential decay was quite different for the hazard stick and the various fuel samples. While the hazard stick moisture curve became quasi-sinusoidal by the end of the second drying day following rains, that of the 0.5 -inch diameter or larger fuel samples remained asymmetrical, with both the daily mean values and the daily amplitudes decreasing, even on the fifth drying day. The duration of decay for the 0.25-inch-diameter hemlock moisture curve was intermediate, lasting ing .94 inches of rain. The time is marked on the abscissa.

for about 3 drying days.

On days when there was a considerable variation in the moisture contents of the outermost layers of the various fuel samples and the hazard stick, an indirect comparison of the daily moisture loss relative to the morning maximum moisture content was made between the fuel samples and the hazard stick.

The difference between the initial moisture content at sunrise (IMC) and the final daily minimum value around 1600 hours (FMC) was utilized as the daily moisture loss, as a percentage of IMC for the various fuel samples $\left(R L_{n}\right)$ and the hazard stick $\left(R L_{h}\right)$

$R L_{n}=\left(I M C_{n}-F M C_{n}\right) \times 100 / I M C_{n}$

$R L_{h}=\left(I M C_{h}-F M C_{h}\right) \times 100 / I M C_{n}$

where $n=1,2 \ldots 7$ refers to the various fuel samples. The ratios of the relative daily moisture losses $E_{n}=\left(R L_{n} / R L_{n}\right) \times 100$

were tabulated according to the number of drying days after the rain (Table 3 ).

The relative daily moisture losses of fuels have been calculated separately for two drying periods so that their consistency both from day to day and as a function of the number of drying days since rain may be examined. 
Table 3 shows that the day-to-day consistency of the relation between fuel and hazard stick moisture

Table 3. Daily moisture losses of fuel samples relative to their daily moisture contents, expressed as percentages of those for the hazard stick.

\begin{tabular}{cllll}
\hline $\begin{array}{c}\text { Fuel type and } \\
\text { size (in.) }\end{array}$ & Drying days since rain \\
\hline
\end{tabular}

Fast Fuels

$$
\text { August } 14-19
$$

$\begin{array}{lrlllll}0.25 \text { hemlock } & 117 & 77 & 59 & 60 & 60 & 62 \\ 0.5 \text { hemlock } & 79 & 57 & 52 & 45 & 43 & 45 \\ 0.5 \text { cedar } & 65 & 56 & 49 & 41 & 39 & 40\end{array}$

Slow Fuels

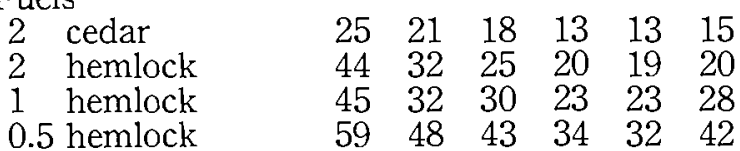

Fast Fuels

August 5-8

$\begin{array}{ccccc}\text { Fast Fuels } & & & \\ 0.25 \text { hemlock } & 37 & 81 & 77 & 73 \\ 0.5 \text { hemlock } & 31 & 61 & 82 & 55 \\ 0.5 \text { cedar } & 31 & 50 & 57 & 55 \\ \text { Slow Fuels } & & & & \\ 1 \text { cedar } & 19 & 19 & 18 & 17 \\ 2 \text { hemlock } & 22 & 36 & 34 & 22 \\ 1 \text { hemlock } & 29 & 36 & 32 & 30 \\ 0.5 \text { hemlock } & 35 & 52 & 49 & 49\end{array}$

losses has no predictable value for any one of the fuels examined. There appears to be a general trend of decrease for the ratios from the first or the second day of drying, but the rate of decrease is highly variable. Also, during the period from August 14 to 19 nearly all the ratios decreased from the first to the fifth drying day, whereas from August 5 to 8 they increased initially for 1 or 2 days, then decreased from the third to the fourth drying day. Since both the amount of rain and the weather during the drying periods influenced the ratios, it appears that the time since rain was an insignificant factor. Furthermore, since hazard stick sorption rates were always greater than those of the fuel samples (Fig. 3), the relationship between hazard stick and fuel sample moisture losses could not be expected to become constant during prolonged droughts. It is concluded, therefore, that counting the number of drying days after the rain would be of little practical value in predicting fuel moisture contents from current hazard stick readings.

One of the more important assumptions behind using individual hazard stick readings as a guide for slash burning is that it provides an estimate of the moisture content of fine fuels, hence of the probability of a successful ignition and fire spread. The apparently contradictory results of some slash burns, at the ignitions of which similar hazard stick readings were noted, suggest that the rate of fire spread and the tendency for spotting are, by them-

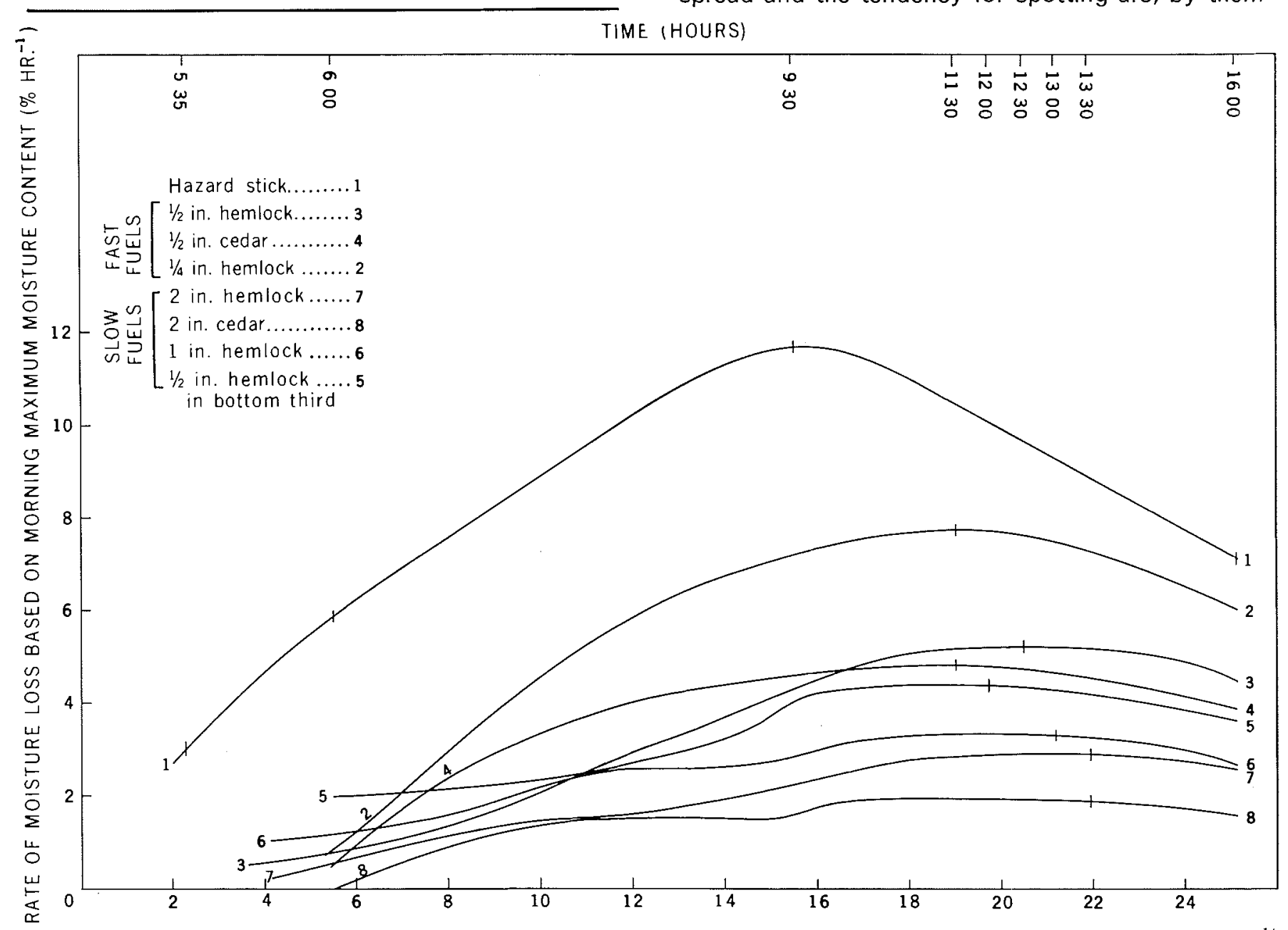

SQUARE ROOT OF DRYING PERIOD STARTING AT THE OCCURRENCE OF THE MORNING MAXIMUM MOISTURE CONTENT (MIN.1/2)

Fig. 3. The relation between the hourly rates of moisture loss, relevant to the morning maximum moisture content, and the square root of drying period for cedar-hemlock logging slash fuel samples and a freely exposed hazard stick on August 9, 1965. 
selves, as ill-suited for indicating the moisture content of the slash as the current hazard stick readings.

Based on the results of 368 slash fires, Morris (1966) concluded that at least two out of three slash fires would ignite and spread readily on southeast exposures when the moisture content of exposed hazard stick is at or below $15.8 \%$ at the time of ignition, and that spot fires would occur in adjoining green timber with stick readings at or below $15.1 \%$. In contrast, Muraro (1964) found, while burning cedar-hemlock logging slash in the interior wet belt, that "winds of 15 to $20 \mathrm{mph}$, steep slopes, or extremely heavy concentrations of continuous fine fuels are necessary to maintain fire spread when the moisture content [of the hazard stick in the open] is in the range of 12 to 15 per cent" (p. 31) 4 .

The discrepancy in the above results can readily be understood by examining the moisture contents of the hazard stick and fast fuels (Fig. 2). Since a hazard stick moisture content of $12 \%$ could represent almost any moisture content between 17 and $22 \%$ for the 0.25-inch-diameter hemlock, between 17 and $26 \%$ for the 0.5 -inch-diameter hemlock, and between 17 and $30 \%$ for the 0.5 -inch-diameter cedar fuel samples during the 5 days following 0.94 inches of rain, the hazard stick readings and the supposed fire behaviour associated with them, as suggested by Morris (1966), probably indicate the concentration of fuel and the meteorological conditions beThese moisture content values were, in error, published in
reference to fine fuels, rather than as hazard stick readings.
Personal communication, Mr. S. J. Murara, Victoria, B.C.
1965.

\section{References}

ANON. 1955. Sunshine, slash, and hazard sticks. B.C. For. Serv., Frotect. Bull. 4, 4 pp., Victoria.

BRYAN, N. D. 1944. Broadcast burning in heavy fuels on rough topography. Proc. West. For. Conserv. Assoc. pp. 30-33.

HARDY, C. E. 1953. Half-inch fuel moisture sticks - how they are made. U.S. Forest Serv. Fire Control Notes 14 (4): $1-8$

KING, A. R. and M. LINTON. 1963. Moisture variation in forest fuels: the rate of response to climate changes. Aust. J. Appl. Sci. 14 (1): 38-49.

LINTON, M. 1962. Report on moisture variation in forest fore and during the slash burns more than the actual fuel moisture contents. Thus, when individual values of hazard stick readings are suggested as a guide for controlled burning of cedar-hemlock logging slash, it should be remembered that the current stick readings alone have little relevance to the actual moisture content of fine fuels, the ease of fire spread, or the tendency of the fire to spot.

The results of the current investigation have been discussed in terms emphasizing the irrelevancy of individual stick readings to the moisture content of cedar-hemlock logging slash. The quantitative analyses of the hourly drying rates (Fig. 3) and of the daily losses of fuel moisture (Table 3) substantiate this contention. The notion that hazard stick and logging slash moisture contents decrease to about the same value on any sunny summer afternoon must be discarded as having no validity during years when the tight bark is retained by the slash.

While the individual current stick readings by themselves are unreliable as indicators of burning conditions, the practice of observing the general trend of the stick moisture over several days, used in combination with the knowledge of the current and forecasted general weather and drought conditions, can be invaluable to protection personnel, especially in timing the ignition of slash.

\section{Acknowledgment}

The author wishes to express his gratitude to $\mathrm{Mr}$. S. J. Muraro, Research Scientist, for helpful discussions and his continued interest during the investigation.

fuels, prediction of moisture content. C.S.I.R.O. Div. Phys. Chem. April 1962, $27 \mathrm{pp}$.

MORRIS, W. G. 1953. Fuel moisture indicator stick as guide for slash burning. Timberman 54 (10): 128 .

moisture 1958. Slash fire behaviour correlates with fuel 59-60.

1966. Guidelines offered for slash burning. Suggestions aimed at broadcast burning of clearcut tracts. Forest Ind. $93(10)$ : 62-63.

MURARO, S. J. 1964. The Wap burn. B.C. Lumberman 48 $(8): 28,30-31$.

1967. Methods and needs for evaluating performance of prescribed fires. Proc. XIV I.U.F.R.O. Congr., Munich, 5 (24): 843-865.
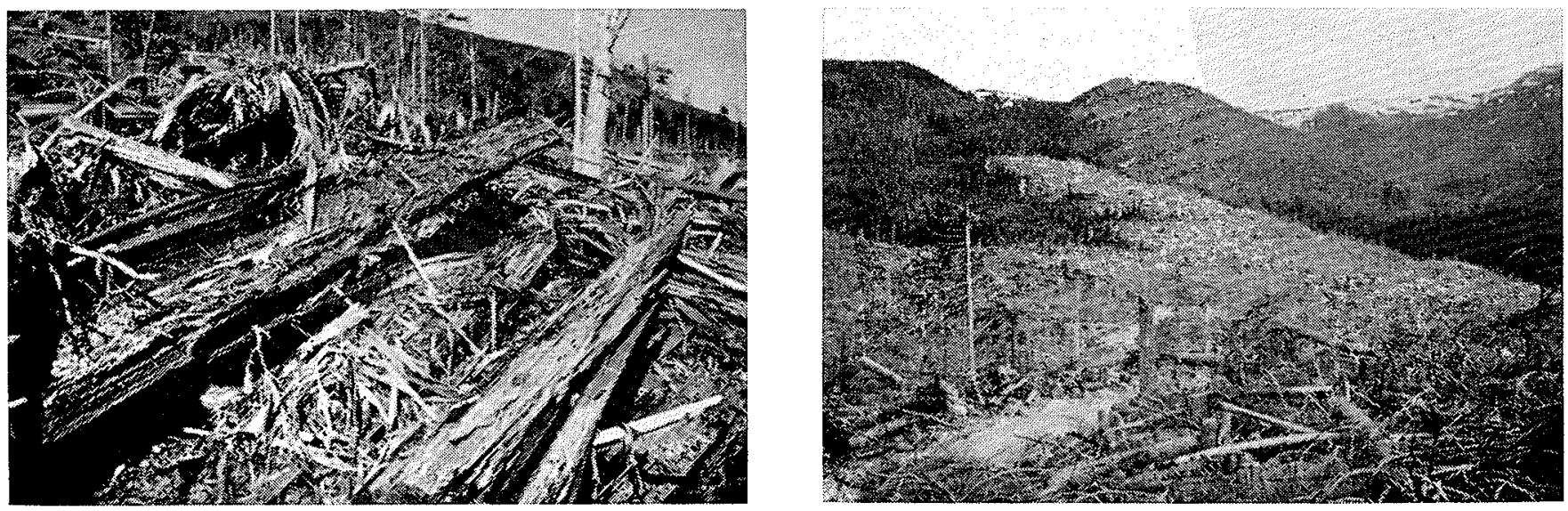

April 1969 The Forestry Chronicle 